\title{
Challenges for Community-Based Forest Management in the KoloAla Site Manompana
}

\section{Journal Article}

Author(s):

Urech, Zora Lea; Sorg, Jean-Pierre; Felber, Hans Rudolph

Publication date:

2013-03

Permanent link:

https://doi.org/10.3929/ethz-b-000064761

Rights / license:

In Copyright - Non-Commercial Use Permitted

Originally published in:

Environmental Management 51(3), https://doi.org/10.1007/s00267-012-0011-7 


\title{
Challenges for Community-Based Forest Management in the KoloAla Site Manompana
}

\author{
Zora Lea Urech • Jean-Pierre Sorg • \\ Hans Rudolph Felber
}

Received: 26 September 2011 / Accepted: 23 December 2012/Published online: 22 January 2013

(c) Springer Science+Business Media New York 2013

\begin{abstract}
Following the IUCN 5th World Congress on Protected Areas in 2003, the then-President of Madagascar decided to increase the area of Madagascar's protected areas from 1.7 to 6 million ha. To combine the aims of protection and timber production, a new concept was developed through the establishment of community-based forest management (CBFM) sites, called KoloAla. However, experience shows that similar management transfers to communities in Madagascar have only been successful in a very few cases. We aimed to explore the success to be expected of this new approach in the particular case of the Manompana corridor at Madagascar's eastern coast. In a first step, the readiness of the corridor's resource users for CBFM has been analysed according to the seven resource users' attributes developed by Ostrom that predict an effective self-organized resource management. In a second step, we explored how KoloAla addresses known challenges of Madagascar's CBFM. Analyses lead in a rather sober conclusion. Although KoloAla attempts to address the goals of poverty alleviation, biodiversity conservation and timber production under a single umbrella, it does so in a rather non-innovative way. Challenges with regard to the state's environmental governance, agricultural inefficiency and thus deforestation remain unsolved.
\end{abstract}

Keywords Madagascar - Community-based forest management - Resource management - Conservation . Participation

Z. L. Urech $(\bowtie) \cdot$ J.-P. Sorg

ETH Zurich-USYS, Zurich, Switzerland

e-mail: urechz@gmail.com

H. R. Felber

ETH Zurich, NADEL, Zurich, Switzerland

\section{Introduction}

Many global conservation and development communities focus on Madagascar's forests, which are not only of high importance for biodiversity but also of home to a highly diverse range of precious woods. Timber and non-timber forest products (NTFPs) contribute significantly to the well-being of rural people (Ramamonjisoa 2004). While the potential of some forest resources is not fully utilized, the availability of forest resources is declining due to overexploitation and agricultural extension (Harper and others 2007). Moreover, a great number of rare woods are exploited illegally (Ballet and Rahaga 2009; Randriamalala and others 2011). For several decades both national and international projects have tried to stop the destruction of natural resources and to find ways to establish a more sustainable forest management. In 1996, the decentralized use of natural resources was legislated, providing the basis for a new concept named KoloAla, which started in 2006. KoloAla is a recently developed approach to protect forests and people alike by means of sustainable, decentralized, community-based forest management (CBFM). To date, community-based forest management projects have rarely been successful in Madagascar (Ballet and others 2007; Froger and others 2004; Pollini 2010), often because they do not offer sufficient financial incentives to local peoples (Hockley and Andriamarovololona 2007) or they are hindered by socio-cultural problems (Andriamalala and Gardner 2010; Kull 2004). Based on these findings, the question arises as to how the concept of KoloAla will confront these challenges of community-based forest management (CBFM), and how much it differs from the already broad range of concepts and approaches that have been tried before. The KoloAla concept has already been implemented in the forest corridor of our study site, which 
includes the three municipalities of Manompana, Ambahoabe and Antenina on the east coast of Madagascar. The aim of this article is to discuss whether the KoloAla concept is the appropriate approach to meet both local inhabitants' needs and national forest conservation interests under the umbrella of one project. We therefore analysed current traditional forest uses, local governance systems, derivation of income through forest products and the general importance of the forest to local livelihoods in the forest corridor of Manompana. In this article, we will discuss the following questions:

1. Are the local inhabitants of the Manompana corridor suitable candidates for a CBFM project?

2. Is KoloAla an appropriate approach for overcoming the difficulties other CBFM projects have encountered?

To answer the first question, we use and discuss in Sect. 3 the seven attributes of resource users that predict a high potential for success in CBFM, developed by Ostrom (1999, 2001). In contrast to the theory that multiple individuals, acting independently, will exhaust a common limited resource even if it is not in everybody's interest for this to happen (Hardin 1968), Ostrom has developed a list of seven attributes for users that predict when collective action or selforganized resource management of common-pool resources by local communities will be effective. These attributes have been elaborated based on a large body of literature and have been discussed in a workshop held by CIFOR in 1997. Although these attributes have been critically discussed, researchers have found them important (Ostrom 1999). A study conducted by Cox and others (2010) evaluated Ostrom's principles based on studies by other researchers. They showed that Ostrom's attributes are empirically wellsupported. More than 10 years after this workshop, they still seem to be the most used and most interdisciplinary set of generalized attributes for analysing self-organized resource management (Fennell 2011; Schlager 2007). We therefore decided to apply these attributes.

Forests in our study site are not entirely governed by the local population; the framework of regulations is given by the state and the authorization for logging activities is managed by the state forest services. However, the state forest services are not present to ensure any control. Although there exist traditional forest ownership with regard to smaller forest fragments in the study site, the access to all forest resources (including timer and non-timber) remains open to all inhabitants (Urech and others 2011). We therefore consider these forests as common-pool resources, as has been done in other studies in Madagascar (Rabesahala Horning 2004).

To answer the second question, we additionally identified how the implementation of CBFM in our study site fits into the cultural context and the local social structures, and what could be major constraints and challenges for the KoloAla approach.
Ostrom's criteria are not optimal for analysing the characteristics of the individual frameworks of CBFM system, as for example KoloAla. Even if resource users demonstrate all attributes to be successful in CBFM, they still need an adequate framework of regulations and institutions that fit the specific local livelihood systems. We therefore compared the constraints and challenges we identified in Manompana with other studies of CBFM success and failure in Madagascar, to see how innovative and adequate KoloAla really is.

\section{From Centralized Forest Management to KoloAla}

In Madagascar, anthropogenic deforestation started when the first human settlers arrived around 350 B.C. (Burney and others 2004). There are many factors that contribute indirectly to deforestation (Jarosz 1993; Shvidenko and others 2008) but the main reason is the slashing and burning of forests on hill sides and slopes to convert the land to rain-fed rice cultivation (Agarwal and others 2005; Pfund 2000), a practice introduced from southeast Asia (Dahl 1991), called tavy. It was in 1881 that prime minister Rainilaiarivony declared the forest state property and banned slash-and-burn practice on forests (Kull 2002; Ramamonjisoa 2004). Nevertheless, until the French colonization, people continued to regard forests as common resources and to apply their local rules and practices (Rakotovao Andriankova and others 1997). During and after colonization the administration tried to exclude the rural population from natural resource management and implemented a general fire prohibition (Bertrand and Randrianaivo 2008). However, due to an insufficient number of forest service employees, fires could not be controlled (Montagne and Bertrand 2006). Gradual deforestation and a troubled relationship between the local population and the state-run forest management did not change even when Madagascar became independent in 1961 (Kull 2004). Natural forests remained state property.

In the mid-nineties, several studies confirmed that Madagascar's natural resource policies had failed (Kull 2004; Rabesahala Horning 2009; USAID 2009). For that reason, a certain responsibility was relegated to the local population through the implementation of a decentralized resource management (Bertrand and others 1999a, b; Kull 2004). A result of this new insight was the introduction of GELOSE (Gestion Locale Sécurisée), a law that partially devolves resource management responsibility of resource management from the state to local institutions (Muttenzer 2006a, b). In parallel to GELOSE, the system of GCF (gestion contractualisée des forêts) was launched (Bertrand and others 2006), enabling a local, decentralized and contract-based forest management. The transfer of a beneficial forest, particularly for timber management, to the local population should result in people valuing natural forests more (Bertrand and others 2009) and thus be an incentive for forest conservation. 
Experience shows, however, that a successful transfer of forest management has only been achieved in a very few cases (ESSA 2008; Rabesahala Horning 2009; Raik and Decker 2007; Razafy 2004). The politics of prohibitions by the state resulted in widely illegal timber exploitation and on-going deforestation (Bertrand and others 2009).

In 2002, Madagascar had a network of 1.7 million ha of protected forests (Hufty and Muttenzer 2002). After the 2003 International World Congress on Protected Areas in Durban, President Ravalomanana signed a declaration to increase the area of 1.7 to 6 million ha (Rabesahala Horning 2010). However, this new Durban Vision to expand protected areas did not consider how to deal with the increasing demand for woody forest products which can only partially be met by plantations (currently around 22 million $\mathrm{m}^{3} /$ year (USAID 2009). Thus, to ensure forest protection and timber production at the same time, the concept, "KoloAla", was established in close collaboration with the international community (particularly the USA) and the Ministry of Environment, Water and Forest (MINENVEF). This new concept intends, with forest zoning to simultaneously embrace sustainable timber production, forest conservation and forest restoration in one "conservation site" (Bertrand and others 2009). In the year 2010, a total of 390,000 ha of forest was designated as KoloAla sites, including the site in Manompana (USAID 2009). In fact, KoloAla is the label for a new generation of community-based forest projects pushed largely by the development community, including a package of approaches building on GCF and in conjunction with previous corridor approaches. However, all different KoloAla sites are part of the broad national forest zoning program (Ferguson 2010).

\section{KoloAla Manompana}

The KoloAla site situated in the Manompana corridor contains 3 communes and 16 fokontany. A fokontany is an administrative subdivision of several villages and hamlets. The KoloAla project has transferred the right for forest management to 16 COBAs (Communauté de base), one for each fokontany. Each $C O B A$ has an unlimited number of voluntary members, one management committee (UFA = Unité d'aménagement villageois), an administrative person and one president (KAM 2009). The COBA as an entity is responsible for realizing the sustainable management of forests, for distributing permits and for controlling and penalizing forbidden actions by local farmers. Moreover, the COBA is obliged to organize the investment of financial revenues in social projects or to distribute benefits. Forest management and revenue-reinvestments are realized on the level of fokontany. In total, the Manompana corridor is composed of three types of zones (Fig. 1):

There is one core zone dedicated to strict nature conservation and forest restoration, which has been identified through satellite images and biodiversity conservation criteria. In every village, there are two more types of zones, one for local consumption and one for commercial exploitation, identified and delimitated together with local inhabitants. KoloAla specialists and village representatives working together determined the allocation of the forest to the different fokontany.

As part of the formalized long-term contract between the community associations and the state forest service, the relevant aspects of the dina are discussed and adapted with the community. The term dina refers to a traditional formal pact that applies the customary law (Henkels 2001). As the state has attempted to incorporate the dina rule-setting institution of "traditional law" into modern law (Kull 2004), this is an important part of the KoloAla management approach. For the elaboration of contracts, a local team of Malagasy specialists facilitates the formation and education of the $C O B A$ members, provides advice and determines the forest zoning. We call these specialists the KAM team (KoloAla Manompana team).

\section{KoloAla Site}

The KoloAla site in Manompana is located near the east coast and comprises 50,000 ha with about 30,000 ha of
Fig. 1 The three different zones in the KoloAla corridor (Source: KoloAla Manompana 2009)

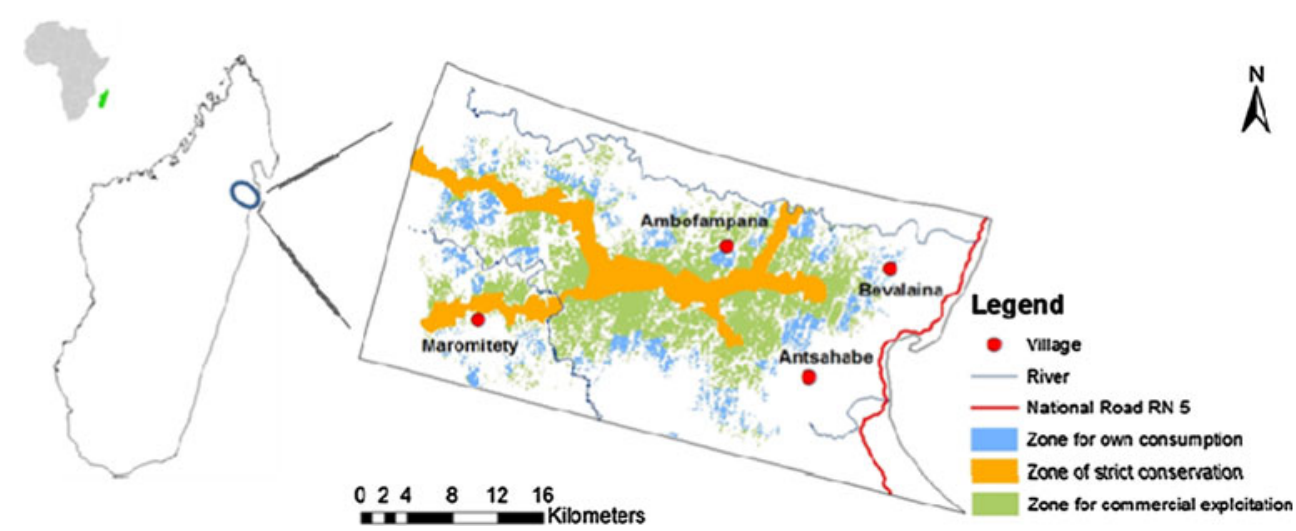


forested landscapes (Rakotomavo 2009) (Fig. 1). It has an average population density of 20 persons per $\mathrm{km}^{2}$ (Pfund and others 2011) and belongs to the district of SoanieranaIvongo, in the region of Analanjirofo. Acting as an important connecting zone between two other large forest areas in the north and in the south, this area is called the Manompana corridor. The implementation of KoloAla in the corridor started in the year 2008 .

\section{Methodology}

Interviews

Data collection based on interviews provides the analytical basis to discuss (1) Ostrom's seven attributes for resource users and (2) possible constraints and the potential of the system of KoloAla in Manompana (KAM). To analyse the role and significance of the forests, particularly the role of cash income generated by forest products, in local livelihoods, we conducted household interviews $(N=110)$. Additionally, semi-structured interviews were conducted in each village with key informants (e.g. village authorities, village elders, members of village associations, KAM team, etc.) $(N=20)$ to explore local rules and governance systems. For data collection, we chose four different villages according to their distance to the nearest edge of the contiguous forest massif (distances of $0.2 / 0.5 / 2$ and $3 \mathrm{~h}$ walking time). Fieldwork was carried out during two field periods, each of 6 months duration, in 2008/2009. All involved researchers worked independently from the KoloAla project team. However, it needed some months to convince local farmers about the research project's independence.

Results have been discussed in two 3-day workshops in 2009 and 2010 with administrative authorities, the KAM team, representatives from the state forest service, national and international researchers and COBA members.

\section{Influence of Wealth}

Households were categorized into 3 wealth levels: poor, intermediate and wealthy. Wealth criteria were based on former research experiences (Adams and others 1997; Carter 2008; Schmidt 2007) and then adapted to criteria given by the local population. For each household, 0-24 points were allocated according to 14 different criteria. These 14 criteria refer to legal and traditional ownership (land, animals, houses, material, etc.), average cash income, agricultural yields and diversity per season, health, need for day labour, alternative income possibilities (other than agriculture) and social position in the village.
Statistical Analysis

To examine if local people's perceptions with regard to the use of forest resources are influenced by (a) wealth level and (b) distance to the forest massif, we applied statistical analysis. All tests were conducted with Pearson's $\chi^{2}$ test.

\section{Seven Attributes of Resource Users for an Effective CBFM, According to Ostrom}

Research has shown in many locations that forest users have organized themselves to protect or manage forests in a sustainable way (Adcharaporn and others 2006; Varughese and Ostrom 2001). However, success depends on many causal variables and processes (Agrawal and Chhatre 2006), the characteristics of the resource users themselves being an important factor. Ostrom (1999) identified seven attributes of resource users that predict a high potential success for CBFM. In the following section, these seven attributes will be discussed with regard to the resource users of our study site.

Salience: Users are Dependent on the Resource for a Major Proportion of Their Livelihood

Forests have diverse significances in local livelihood systems. In particular, forests act as land reserves and are thus of high importance for the local population. $87 \%$ of all families $(N=101)$ say that they depend on forests. However, this importance often leads to deforestation. We therefore focus on the importance of forest resources themselves and not on the importance of the forest as a soil reserve. In the study site, all the investigated families $(N=110)$ harvest forest products for house construction and $91 \%$ harvest NTFPs for their personal consumption or to generate cash income. The annual average cash income per household from NTFPs and timber is between 3 and $12 \%$ of what Rakotoarison (2009) analysed as the average annual cash income per household from agriculture. This is very low compared to other regions of Madagascar, where researchers found that the villagers derive as much as $31 \%$ of their subsistence-based economy from forest products (Shyamsundar and Kramer 1996). Moreover, $59 \%$ of the questioned families believe that they are able to survive without natural forests, even though they use forest resources almost every day. Although houses are built with forest resources, people argue that alternative natural materials from other landscapes could replace these materials, even if they are of lower quality. Similarly, fuel wood can be found in secondary vegetation or agroforestry systems. Farmers see their dependency strongly related to the substitutability of forest products through cultivated, 
bought or alternative natural products. Results suggest that all people use forest resources but are not unconditionally dependent on them. Dependency is a definition that depends on individual judgement; thus, it is difficult to predict whether people are truly dependent on forest resources or not. According to those interviewed, the most important role of forests is their function as soil reserves, not the forest resources themselves.

Common Understanding: Users have a Shared Image of the Resource and How Their Actions Affect Each Other and the Resource

People from the four villages in our study site have rather similar understandings in terms of rule interpretation, acceptance of traditional authorities and use of forests. Most families, poor or wealthy, immigrants or not, follow the same rules of access or ownership and respect differing taboos between lineages or families. A traditional understanding of forest ownership exists in the case of smaller forest fragments but only refers to the right to forest clearance and is well respected by villagers (Urech and others 2011). In contrast to other regions (Samisoa 2001), deforestation is not considered to be a problem caused by migrants. But with regard to how "their actions affect each other", images differ. To analyse differing images, we asked three main questions.

For the first question $(N=78)$, we asked: "What are the consequences of deforestation on your family's wellbeing?" $59 \%$ of all families see negative consequences. The negative consequences cited are that families will need more time to find necessary products $(N=16)$, income through timber of NTFP will decrease $(N=13)$ and that forest products will be of lower quality $(N=7)$.

However, $41 \%$ of all families think that the disappearance of the forest has no significant influence on their livelihoods, or they think that their livelihood strategies will change as the forest disappears but in ways that are neither positive nor negative. We did not find a significant difference in opinions among people of different wealth levels (Pearson's $\chi^{2}=2.106, \mathrm{df}=2, p=0.334$ ) or distance to forests (Pearson's $\chi^{2}=2.314, \mathrm{df}=3, p=0.510$ ).

For the second question $(N=105)$, we asked whether people "would agree with putting an end to slash-and-burn of natural forests". Although we did not find a significant difference between wealth levels, answers differed significantly between villages (Pearson's $\chi^{2}=36.107, \mathrm{df}=3$, $p>0.001$ ). In the village closest to forest, only $4.2 \%$ of those questioned agreed, while $68 \%$ of those interviewed in the village farthest from the forest were in favour of ending slash-and-burn of natural forests. However, almost all farmers noted that it will be difficult to stop slash-and-burn practices because of the need for more arable land for future descendants.

After discussing the negative and positive consequences of deforestation and the varying importance of forests for livelihoods, we asked a third concluding question $(N=94)$ : "Could you survive without forests, without experiencing fundamental problems?" The majority (59\%) of families have the opinion that they would be able to survive without natural forests; interestingly, this response was not significantly related to wealth level (Pearson's $\chi^{2}=1.497, \mathrm{df}=2, p=0.473$ ). The difference between villages is much more significant, ranging from 42 to $85 \%$ of respondents (Pearson's $\chi^{2}=13.33$, df $=3, p=0.004$ ). Families in the village farthest from the forest massif had the highest positive response rate, perhaps because they have already experienced a high disappearance of forests and have come to recognize that they can still survive. However, even in the village closest to the forest massif, $79 \%$ of all families share the opinion that they would be able to survive without natural forest.

As in the previous section, results indicate that perceptions vary considerably between villages. We therefore cannot assume a common understanding among users.

Discount Rate: Users have a Sufficiently Low Discount Rate in Relation to the Future Benefits They Will Gain from the Resource

Calculations of the discount rate and the future benefits were simplified for the discussion of this publication. Exact values for the benefits and discounts for families resulting from timber trade cannot be calculated because legal timber trade has not yet been implemented. Due to a lack of data, we could not explicitly analyse this attribute but rather interpret it based on other material. We therefore want to point out what future benefits forest resources may supply under CBFM. We also show what general profit losses farmers will have to accept if CBFM is applied.

In the case of Manompana, future benefits to be achieved by CBFM will include alternative income generated by the timber trade, the improvement of social institutions, such as schools and health centres, which will be financed by revenue from the timber trade, the improvement of environmental services such as water supply and soil protection, as well as the sustainable production of timber, fuel wood and NTFPs in the future.

The profit loss resulting from CBFM that people have to accept results from the decreasing possibility for agricultural expansion. To compensate, the rotation periods of the remaining land will likely be shorter, which will result in a loss of soil fertility and decreasing agricultural production (Pfund 2000; Styger and others 2007). Moreover, farmers will have to change a crucial part of their culture: farmers 
will no longer be able to expand their agriculture onto forested land. The practice of cultivating ancestral lands to connect future descendants with the ancestors is a deeply rooted cultural desire, and as described by Keller (2009) "the most important aim in life".

Working at a similar study site, Shyamsundar and Kramer (1996) estimated that families would be willing to accept an end to current deforestation practices if they received an annual compensation of 35 Euro per family. According to analyses regarding the potential economic value of precious woods in Manompana (Rakotomavo 2009), a gross revenue of 35 Euro per family could easily be achieved in some villages through timber exploitation. However, the distribution of revenue by the COBAs is not yet organized and many families may not benefit directly from cash income. We therefore argue that neither exact benefits nor real benefit losses can be estimated in a way that would be representative for all households and include all benefits and losses that people accrue in reality. Moreover, it is not the net amount of future benefits that is crucial, but rather the evenness of the distribution of benefits.

Distribution of Interest: Users With Higher Economic and Political Assets are Similarly Affected by the Use of the Forest as an Open-Access Resource

According to Tole (2010), communities with high levels of wealth differentiation have very low levels of collective management. The differentiation among the three wealth levels in our study site is not high. Intermediate and wealthier households depend on forest resources as much as poor households for house construction, fuel wood or cash income from forest products in times of food shortage or crisis. Moreover, we could not find a significant difference between wealth levels in terms of NTFP collection or trade of NTFP and timber.

We also analysed if forest owners and non-owners are equally represented among the three wealth levels. Traditional forest ownership rules provide the right to convert forest into agricultural land. Forest owners therefore have soil reserves and the possibility for agricultural expansion, as well as much greater interest in maintaining the traditional forest management rules than farmers without forests. They will probably try to maintain their influence on forest management, whether CBFM is implemented or not.

However, we could not find a significant difference with regard to the relationship between forest ownership and wealth. Forest owners are more or less equally represented at all wealth levels. Also, we did not find a significant difference between forest ownership and forest proximity. Thus, the distribution of interest between people of different wealth levels or forest proximity does not seem to vary much.

Trust: Users Trust Each Other to Keep Promises and Relate to One Another With Reciprocity

The primary source of trust in the traditional society in Madagascar is the so-called fiahavanana (social cohesion) which incorporates an idea of proximity, solidarity and cohesion that creates "a fictive affinity between individuals" (Andriamalala and Gardner 2010). According to Andriamalala and Gardner, the fiahavanana can go beyond the circle of family and lineage to include other community members who are not related by blood. This system implies for its members the will to share values and to respect common rules. All villages in our study site are organized by traditional authorities, as is the case in other regions (Cole 2001; Randrianatoandro Andrianavalona 2009). With regard to forest management and conflict resolution, we could observe that these authorities are well-accepted. In traditional farming systems, farmers relate strongly to one another to cultivate agricultural fields. Based on discussions and observation, we suggest that social cohesion is also facilitated in our region by fiahavanana. However, we cannot predict whether individuals trust each other or not, but people definitely trust traditional authorities.

Autonomy: Users are Able to Determine Access and Harvesting Rules Without External Authorities Countermanding Them

The authority of users is only partially supported by actual forest laws and forest management transfers. Under GELOSE, the local population was legally given the responsibility to govern their forests. However, the ownership of all natural forests is still in the hands of the state. Moreover, CBFM projects in Madagascar follow previously devised concepts, strongly influenced by western initiatives. The local population can only accept a concept and influence some particular points; fundamental changes are almost impossible to implement.

Of course, the main responsibility for management is given to local communities under CBFM. However, even if contracts are signed there is no guarantee that the local population will maintain control of their community forest; in other regions, transferred forests were rescinded because of the state's interest in mining (Bertrand and others 2008). Among villagers mistrust against the state's forest regime is usual. This fact has also been noted for other regions on the island (Ecole Supérieure des Sciences Agronomiques 2008). Muttenzer (2010) even refers to the forest service as the "greatest source of insecurity". 
Prior Organizational Experience: Users have Learned at Least Minimal Skills of Organization Through Participation in Other Local Associations

Based on questionnaires, we discovered that prior to the arrival of KoloAla in Manompana, no local association apart from the sport association existed in three of the four villages analysed. In only one of the villages, a group of traditional forest owners developed a well-recognized organization to protect the largest remaining forest fragment in their village territory.

Nevertheless, villages are organized to resolve conflicts among villagers, which requires a particular organizational experience. Traditional bodies composed of village authorities and village elders conduct conflict resolution. These groups have a strong influence on the lives of local people. Even though organizational experience is very low, the existing knowledge and high influence capacity of traditional bodies may offer considerable potential for CBFM.

\section{Discussion About Resource Users’ Attributes}

Two of the seven attributes of resource users that predict an effective resource management are clearly present in the Manompana corridor. First, the distribution of interest among resource users seems to be even. Most users have a shared view of forests and all users are more or less similarly affected by the use of forest resources. Second, people trust village authorities and respect customary rights.

Two attributes are neither really absent nor really fulfilled. First, all users depend on forest resources in the sense that they use forest products in their daily activities and to gain some additional cash income. However, they do not perceive themselves as dependent on these resources and see the primary role of forests as soil reserves for future agricultural conversion. Second, organizational experience is very low; however, a certain traditional skill by village authorities and village elders could have an important potential.

The local population does not fulfil three attributes. First, the understanding of how deforestation affects livelihoods differs significantly between villages, and is in some cases influenced by the distance of the villages from the forest massif. Second, with the current politics, laws and existing approaches for forest management, users are not able to determine access and harvesting rules without external authorities countermanding them. Finally, it remains unclear if future income through forest management equally benefits the local population and if such income will be higher than the discount rate.
Thus, one may conclude that the conditions in Manompana are not suitable for a successful CBFM. On the one hand, the characteristics of the population do not seem adequate for such a transition; considerable support and social capacity-building will be needed before communitybased management will work. On the other hand, the state has a fundamental function with regard to supporting the local population and to enhancing livelihoods, but it does not yet seem willing or prepared to conform to its duties.

We also have to conclude that some of Ostrom's attributes could only be assessed with a certain ambiguity. The assessment of the discount rate required clear numbers, which are hard to obtain before CBFM is implemented. And it is nearly impossible to integrate values that cannot be expressed in numbers (e.g. cultural or spiritual values), but which we consider absolutely necessary. Moreover, the analysis of trust depends on personal interpretation. To assess whether farmers trust each other or not is a highly difficult task for outsiders, even for Malagasy researchers living in other regions. We think that it might be unnecessary for all users to trust each other, but rather important that users trust traditional authorities, which again depends on personal interpretation. To finally conclude whether resource users will successfully realize CBFM also depends highly on the specific framework and regulations of the CBFM system to be implemented at a particular site. It is not only necessary that resource users fulfil Ostrom's attributes but also that the CBFM framework is adapted to local livelihood systems and that resource users are supported by the responsible sate service. We would therefore like to complement the analysis of Ostrom's attributes with an additional analysis of the KoloAla approach in the following section.

\section{The Challenges of CBFM: Is KoloAla Innovative Enough?}

This section is based on a qualitative study. We compared the approach of KoloAla in Manompana (KAM) with the existing traditional management system. The main identified constraints and challenges are categorized into three subsections: (1) meeting local realities with CBFM, (2) forest zoning and COBAs and (3) control and monitoring after the implementation of CBFM. All challenges are discussed in relation to other studies and evaluations regarding the success and failure of CBFM in Madagascar.

\section{Meeting Local Realities with CBFM}

Madagascar is well-known for its severe environmental problems and has become a key site for global environmental governance (Duffy 2006). In the absence of state 
capacity to devise, carry out and finance its own environmental policies, foreign donors have been able to dictate how conservation should be carried out (Rabesahala Horning 2008). The majority of environmental activities are initiated by external non-governmental organizations (NGOs). As a result, most CBFM projects have been discredited as external concepts applied to local realities (Duffy 2006; Muttenzer 2010) without much regard for local interests and concerns. As participation has become a keyword for forest management since its introduction in the nineties (Buttoud 2006), conservation interests have attempted to harmonize with local interests by actively involving farmers in the elaboration of management rules and zones and by integrating their customary rights in legal dinas (Kull 2004; Muttenzer 2006a, b). However, the successful harmonization of conservation ideas and local livelihood systems and interests is seldom achieved (Dirac and others 2006; Keller 2008; Muttenzer 2010). It has been shown all over the world that forest management systems are more likely to have sustainable outcomes when local forest users participate in forest rule-making (Persha and others 2011).

\section{Involvement of Local Inhabitants to Identify Local Rules, Power Relations and Knowledge}

In the case of KAM, the KAM team has involved the local population since the beginning of the project. Through discussions with villagers, the team first identified forest borders of village territories and the areas preferred for different management zones, as well as sites with specific cultural significance. Researchers investigated the role and availability of the most important NTFPs, as well as traditional governance structures and authorities to consider them in $C O B A$ 's formalized contracts.

However, zones were discussed with maps and as most of the farmers cannot read maps, they could not knowledgeably enter the discussion about forest borders and zones. This resulted in disagreements once the zones have been designed. Furthermore, most village members do not speak up in front of village elders or powerful families. Even though discussions and elections of village representatives organized by the KAM team had been conducted with as many villagers as possible, decisions may not have broad acceptance by village members. The structure of the old social order (Henkels 2001), in which the oldest member holds the last word and the population votes according to his word, challenges the principles of participation. This traditional social order enhances the risk of reinforcing the power of an elite minority. A deep understanding of local power relations, hierarchies between social categories of people, generations and gender are necessary to identify local interests and to prevent future conflicts. This, however, would hardly be possible in an area of 100,000 ha with 16 fokontany and hundreds of little villages that can only be reached by foot, each of which has their own power relations and social structures. Such a task could not be realized before implementing KoloAla.

Moreover, by studying the management plan of one COBA (KAM 2009) developed by the KAM team, one could argue about the extent to which local villagers actively participated in rule-setting. For instance, one can hardly imagine that women agreed to collect NTFPs only in some designated areas, as they have traditional rules to distribute Pandanus collection over the whole village territory. Women know very well that collection must be distributed so as to not endanger the plant's regeneration (Fedele and others 2011).

Although villagers could discuss and communicate their interests, the local population did not make the final decisions regarding rule setting. The zones for biodiversity conservation, for example, where forest exploitation is strictly forbidden, have been determined by satellite images and not together with the local population. Hence, to what extent can the implementation of a natural resource management plan based on the concept of KoloAla really be participatory? The principle framework of KoloAla was devised before the integration of the local population into participatory discussions. The question of whether participation is not merely the manipulation of peoples' views and expectations to bring them into line with previously devised plans, raised by Samyn (2006), seems quite relevant in the case of KoloAla.

\section{Meeting Local Interests with CBFM}

Around $79 \%$ of the families in the corridor live below the poverty line (INSTAT 2007) and in extreme poverty (Colfer and others 2011). Almost all the families are subsistence farmers, depending on the cultivation of mountain rice. In the whole corridor, agricultural production has only been addressed by some NGOs, and then only close to the road, not in the hilly hinterland of the corridor where deforestation actually takes place (Rabenilalana and others 2010). Actually, timber trade occurs based on illegal market systems and sometimes corrupt state control (Randriamalala and others 2011). Following the implementation of KoloAla and a legal framework for forest exploitation, the legal timber trade should increase cash income considerably, making farmers less dependent on agricultural production. But it remains debatable as to whether it is realistic to focus solely on the forest for combating poverty and ensuring resource conservation, particularly when the majority of the population lives from subsistence farming. Sodikoff (2009) described in the 
Biosphere Reserve Mananara Nord ${ }^{1}$ that persons now living from income earned by conservation activities are still dependent on family members planting rice on tavy and deforested land. Although they gain money to buy rice, they still buy it from farmers or family members in the region. Thus, increasing income is a step in the direction of poverty alleviation, but CBFM alone cannot simultaneously feed the growing population of Manompana (CARE 2005) and decrease tavy on cleared areas.

Adapted practices for yield improvements or for avoiding soil erosion are not known in Manompana. No single farmer is working with intensified rice systems or other improved techniques, such as the direct planting on permanent soil cover (Husson and others 2003) promoted by CIRAD $^{2}$. So how can farmers stop their well-known practices of tavy if they do not know any alternative? Uphoff and Langholz (1998) have demonstrated at Ranomafana that CBFM can be enhanced by strong yield improvements on irrigated rice fields. In Ranomafana, they searched for more attractive agricultural systems which could replace the traditional tavy. Although increasing yields on irrigated rice fields alone is no guarantee that tavy will decrease, it offers a great potential for combating poverty and lean seasons.

Nevertheless, agricultural expansion and deforestation is due to not only agricultural production but also ancestral customs, as also described in the Masoala region by Keller (2008). Forests are primarily a resource to ensure subsistence and the continuity of the lineage. The interest in conserving forests only rises when forest resources become scarce and cannot fulfil the needs of the families. Another important point for KAM to consider is that villages with already scarce forest resources might be much more interested in CBFM than villages with large remaining forests. It could therefore be an advantage that KAM includes the whole corridor, even villages with little remaining forest.

However, the interest of people in preserving forests can only be raised when measures have a positive impact on their well-being (Adams and others 2004). Thus, CBFM should meet the interests of the local population. With its high economic potential, the timber trade could actually lie at the centre of peoples' interest. But the necessary framework for sustainable management is far from their local realities. The key interest of farmers, cited by almost $100 \%$ of those interviewed, is in increasing agricultural yield, not conserving forests. Environmental politics in general and CBFM in particular should thus be placed in a larger framework of strategies that includes the whole

\footnotetext{
${ }^{1}$ Mananara Nord is a commune situated on the east coast of Madagascar, north of Manompana.

${ }^{2}$ Centre de coopération Internationale en Recherche Agronomique pour le Développement.
}

complexity of poverty reduction and sees forests as one part of a larger, interactive landscape.

\section{Forest Zoning and COBAS}

By formalizing dinas as legal rights into contracts, the responsibility of the local population for resource management is confirmed (Bertrand and others 1999a, b). Despite this legal affirmation, the principal rules and regulations are imposed by the state under KoloAla, as in former approaches for management transfers (Serpantié and others 2008). In many cases, important customary or ancestral rights are ignored by external NGOs while others are adapted to legal state rules, which lead to a deceptive understanding of CBFM by the local population and thus to conflicts (Andriamalala and Gardner 2010; Kull 2004). Traditional tenure rights are still mostly ignored by CBFM approaches (Muttenzer 2006a, b). We will discuss two specific issues with regard to tenure rights that could be problematic in the case of Manompana.

\section{The Zoning of Forests by Fokontany}

Forest borders have been identified and classified into three different zones with the participation of the local population. These forest zones refer to the fokontany territory. However, traditional forest management does not refer to village or fokontany territories, but to the resource allocation of different lineages (Keller 2008; Muttenzer 2006a, b). Forests of a lineage can go beyond the territory of a fokontany and are not limited to the administrative territories. Fokontany is an administrative subdivision introduced by the state for better administrative control and is far from traditional custom (Cole 2001). Villages have no clear borders; they can change depending on the situation, interests and purpose, a fact also described in the literature for other regions (Kull 2002; Leach and others 1999). This unity does not refer to a homogenous interest group with clear boundaries and natural resource allocation. Andriamalala and Gardner (2010) noted that if natural resources are managed by several social groups, complications and conflicts arise. We suggest that this will be the case in Manompana as long as forests are managed by $C O B A$ s that are not related to lineages. What is needed in Manompana is a structure of governance able to resolve conflicts between social groups and different stakeholders, an institution able to affect continuous negotiation, communication and conflict management (Colfer 2005). The potential and knowledge of traditional village institutions to resolve conflicts between villagers has been identified and must absolutely be integrated into $C O B A$ 's structures. Additional skills for continuous conflict management should be developed in all COBAs during the initial phase. 


\section{Forest Owners-Members of COBAs}

Customary rights with regard to forest management define the conditions of open access to forest resources for the whole corridor. These include the right to convert forests for agricultural expansion and the distribution of forested land to immigrants. Traditional forest owners and traditional village authorities are both well-accepted by the local population, as is the case in other regions of Madagascar (Aubert 2008). If these authorities and traditional owners are ignored by KoloAla, forest management may, according to Muttenzer (2006a, b), continue with two parallel legal systems: one based on the introduced KoloAla rules and one based on the traditional customary rights. This leads to confusion and the continuation of tavy on natural forests.

Traditional forest owners and village authorities should be represented in $C O B A$ s. The KAM team tried to achieve the integration of traditional authorities by asking the local population who should represent the village for discussions and problem resolution. However, interviews showed that lineages that are the accepted owners of large areas and therefore have much influence on traditional forest management were not taken into consideration. This is not surprising, as the KoloAla concept of CBFM attempts to avoid privileging forest owners or powerful lineages. These lineages cannot be ignored, however, as they constitute the daily reality of the local population and have considerable power. Some lineages or forest owner may therefore continue to abide by customary rights rather than by the legal rules of KAM.

Control and Monitoring After the Implementation of CBFM

The implementation of CBFM is in itself a difficult challenge. A related, equally important concern is the continued monitoring and control of CBFM, which should be undertaken by the communities themselves, thereby guaranteeing sustainable management.

\section{Support and Mentoring of COBAs}

Until now, CBFM in Madagascar has always been implemented with the support of external institutions and NGOs. Once the $C O B A$ s were established, the management zones identified and contracts signed, local communities had to continue on their own (Rambeloarisoa and Razafy 2008). Long-term support, instruction and mentoring by external institutions failed in most cases (McConnell and Sweeney 2005; Muttenzer 2010). In general, support is available for a maximum of 3 years, a period certainly not long enough for communities to develop the social capacity to run and monitor CBFM independently (Bertrand and others 2008).
At the time of this writing, the support and instruction of KAM have been in place since 2007. Team members have been present and have repeatedly visited even the most remote villages of the corridor. Inventories, market analysis (Sola 2010), long-term management plans and annual harvesting plans have been designed by the KAM team in collaboration with the local population. This is a valuable and rather unique support for COBAs. Nevertheless, the population is still strongly influenced by mistrust against the state and external forest organizations (ESSA 2008). To regain the trust of the local population, stable and longlasting backing by the government as well as governmental faith in the local population is needed. However, this issue can only be addressed in part by KAM, as it is strongly a factor of national politics.

\section{The Role of the State}

Environmental initiatives in Madagascar are often based on project frameworks financed by donors and do not follow a homogeneous national government strategy (Ramamonjisoa 2004). As a result, such initiatives do not reflect a state impulse or major interest. This is clear when considering the fact that for the whole region of Analanjirofo (1.2 million ha of forests), the state forest service has one person who is responsible for the control and monitoring of all forests. Due to the non-existent personnel capacity, control and announcement of illegal activities must be conducted by the local population itself, by the COBA. However, for local farmers it is a nearly impossible task to exclude outsiders, and to punish or accuse farmers from the same region (Sodikoff 2009). The exclusion of outsiders remains a problem, also for KAM. Loggers, for example, are typically from outside of the fokontany territory. Following customary rights of open access, this is allowed. This open access will have to be limited and controlled by local farmers under CBFM. However, the local population is confronted with the challenge of how to exclude or punish persons who are not officially permitted to log but who are members of the same lineage or even family. Individuals depend on the ancestral systems of fiahavanana (Andrianananja and others 2006). As each individual depends on this network, it is often impossible to betray someone of the same "family" (Andriamalala and Gardner 2010; Sodikoff 2009). Similarly, it is difficult to exclude neighbouring populations from access to the many resources of forests (McConnell and Sweeney 2005). Although this problem is well recognized, it is ignored by the state.

Without strong state support that assists with the continuous control of forest management, CBFM will not succeed (Rambeloarisoa and Razafy 2008). KoloAla is integrated in a national concept with a homogeneous 
strategy for several sites in Madagascar. KoloAla has the potential to help the state evolve a national concept of support and monitoring for local communities. Nevertheless, the state must take initiative itself, and global donors should support Malagasy's initiatives rather than pushing their own ideas.

\section{Conclusion}

Ostrom described seven attributes of resource users that should be fulfilled to predict successful community resource management. Our results showed that with regard to the rural dwellers of the Manompana corridor, only two of these attributes are fulfilled completely, and another two only partially. Three attributes are not fulfilled at all. Hence, we suggest that the question posed in the introduction "are local inhabitants of the Manompana corridor suitable candidates for a CBFM project?" can be answered with "no".

This should not be interpreted as a definite conclusion, however, as some of these attributes are difficult to measure (e.g., users' dependency on the resource or the discount rate). Moreover, some of the attributes could and should be enhanced by improving the capacity of the state forest services to support local villagers. Organizational experience can be learned, and to cope with the fact that people do not have a shared understanding of the importance of the forest, different interest groups should be involved in the decision-making process. We conclude that the resource users' attributes are an important indication for the success of CBFM, but are heavily dependent on the CBFM approach and the support they receive from external organizations or the state.

The discussion about CBFM's challenges in Madagascar shows that KoloAla in Manompana, as many former CBFM projects, is confronted with well-known constraints. Moreover, people in the study site live in highly remote areas where the poverty rate is extreme and agricultural production remains at the lowest level in the country. Due to the difficult circumstances of the local population, challenges to realize CBFM might even be greater in Manompana than elsewhere, and combating poverty with only CBFM may be a difficult or almost impossible task. KoloAla is another approach toward establishing decentralized resource management. However, like earlier approaches, KoloAla has to tackle the deeply rooted culture of tavy, the high poverty rate and differences between western ideals and local understanding. These realities of rural areas in Madagascar have not changed and despite many negative conclusions about former CBFM projects, there is no fundamental evolution in the concept of KoloAla.
Moreover, the lack of motivation and field personnel in the state forest service, both of which have significantly limited the success of earlier projects, will represent major challenges for KoloAla again. And the current political instability does not contribute to a more legal and transparent timber exploitation supported by a strong state forest service. Madagascar surrenders issues of natural resource conservation to the international community and seems either unwilling or unable to resolve problems on its own. The same is true for the agricultural sector, which is tightly linked to deforestation. Agricultural production remains low, technical support is non-existent, particularly in remote areas, and the problem of poor market access remains unresolved. Unfortunately, while the state ignores the association between agriculture and forestry, the concept of KoloAla seems to separate these two sectors once again. The most important issue for the local population in the Manompana corridor remains agricultural production, which is far from being enough to feed even just the producers themselves. Until this fundamental problem has been at least partly resolved, people are neither willing nor able to be interested in CBFM.

To answer the second question posed in the introduction, "is KoloAla an appropriate approach for overcoming the difficulties other CBFM projects have encountered?" we suggest that KoloAla alone is not innovative enough to overcome existing challenges without a stronger collaboration with the state. Without the full acceptance of customary land tenure rights and the merited responsibility for rural dwellers, combined with a strong desire by the state to change the context of rural realities, KoloAla may encounter the same problems and failures as many earlier projects.

Acknowledgments We would like to thank the organizations that have helped fund our research: The Research Fellow Partnership Program (RFPP) of the North-South Center at the ETH Zurich, the Commission for Research Partnerships with Developing Countries (KFPE), and the Swiss Agency for Development and Cooperation (SDC). Furthermore, we thank AIM (Association Intercooperation Madagascar); the KoloAla Manompana team and especially the local households who made this research possible by freely sharing their lives and information with us; Erin Gleeson for fundamental comments and English proof-reading, and the reviewers for important and valuable inputs and recommendations.

\section{References}

Adams AM, Evans TG, Mohammed R, Farnsworth J (1997) Socioeconomic stratification by wealth ranking: is it valid? World Dev 25:1165-1172

Adams W, Aveling R, Brockington D, Dickson B, Elliot J, Hutton J, Roe D, Vira B, Wolmer W (2004) Biodiversity conservation and the eradication of poverty. Science 306:1146-1149

Adcharaporn P, Yeon-Su K, Daugherty PJ (2006) What makes community forest management successful: a meta-study from 
community forests throughout the World. Soc Nat Resour 19:33-52

Agarwal DK, Silander JA, Gelfand AE, Dewar RE, Mickelson JG Jr (2005) Tropical deforestation in Madagsacar: analysis using hierarchical, spatially explicit, Bayesian regression models. Ecol Model 185:105-131

Agrawal A, Chhatre A (2006) Explaining success on the commons: community forest governance in the Indian Himalaya. World Dev 34:149-166

Andriamalala G, Gardner CJ (2010) L'utilisation du dina comme outil de gouvernance des ressources naturelles: leçons tirés de Velondriake, sud-ouest de Madagascar. Trop Conserv Sci 3:447-472

Andrianananja H, Raja K, Sirven N (2006) Réseaux de parenté de Manjakatompo: La gestion communautaire de la forêt. Économie rurale 294:27-40

Aubert S (2008) Autorités coutumières et régulation sociale. In: Aubert S, Razafiarison S, Bertrand A (eds) Déforestation et systèmes agraires à Madagascar. Les dynamiques des tavy sur la côte oriental, CIRAD, CITE, FOFIFA, pp 107-132

Ballet J, Rahaga N (2009) Impact économique des arrêtés autorisant les exportations de bois précieux à Madagascar: 2009. PGM/ GTZ

Ballet J, Sirven N, Requiers-Desjardins M (2007) Social capital and natural resource management. A critical perspective. Environ Dev 16:355-374

Bertrand A, Randrianaivo D (2008) Tavy et déforestation. In: Aubert S, Razafiarison S, Betrand A (eds) Déforestation et systèmes agraires à Madagascar. Les dynamiques des tavy sur la côte orientale, CIRAD, CITE, FOFIFA, pp 9-34

Bertrand A, Babin D, Nasi R (1999a) L'adaptation de l'aménagement forestier à des situations diverses. Bois et forêts des tropiques 261:39-49

Bertrand A, Babin D, Nasi R (1999b) L'adaption de l'aménagement forestier à des situations diverses. Bois et Forêts des Tropiques 261:39-52

Bertrand A, Montagne P, Besse F, Serre-Duhem C, Raharimaniraka L (2006) Nouvelle politiques forestières et gestion économique publique des filières des produits forestiers non ligneux. In: Betrand A, Montagne P, Karsenty A (eds) Forêt tropicales et mondialisation. Les mutations des politiques forestières en Afrique francophone et à Madagascar, L'Harmattan, pp 243-275

Bertrand A, Serpantié G, Randrianarivelo G, Montagne P, Toillier A, Karpe P, Andriambolanoro D and Derycke M (2008) Une gestion locale durable et porteuse de développement ou un retour aux barrières: quelle place pour le transfert de gestion dans la construction des nouvelles aires protégées malgaches? Pages 39-51 in: Colloque International "Les parties prenantes de la gestion communautaire des ressources naturelles: coopération, contradictions, conflicts". Département des Eaux et Forêts de l'ESSA, Université d'Antananarivo, Antananarivo, Madagascar

Bertrand A, Rabesahala Horning N, Montagne P (2009) Gestion communautaire ou préservation des ressources majeure de la politique environnementale à Madagascar. VertigO 9:1-18

Burney DA, Burney LP, Godfrey LR, Jungers WL, Goodman SM, Wright HT, Jull AJT (2004) A chronology for late prehistoric Madagascar. J Hum Evol 47:25-63

Buttoud G (2006) Participation in forest policy processes: apple-pie, or new mode of governance? Schweizerische Zeitschrift für Forstwesen 157:429-430

Carter J (2008) Project Kolo Ala Manompana: Mission report. Adressing vulnerability in project activities. Bern

Cole J (2001) Forget colonialism? Sacrifice and the art of memory in Madagascar. University of California Press, Berkeley

Colfer CJP (2005) The complex forest communities, uncertainty, and adaptive collaborative management. Resources for the Future, Washington, DC
Colfer CJP, Pfund J-L, Andriampandry E, Asaha S, Boucard A, Boissiere M, Feintrenie L, Ingram V, Lyimo E, Martini E, Rantala S, Roberts M, Sunderland T, Urech ZL, Vihemaki H, Vongkhamasao V and Watts JD (2011) An introduction to five tropical landscapes, their people and their governance. In: Colfer CJP, Pfund J-L (Eds.), Collaborative governance of tropical landscapes. Earthscan, pp 1-34

Cox M, Arnold G, Villamayor Tomás S (2010) A review of design principles for community-based natural resource management. Ecol Soc 15:38

Dahl OC (1991) Migration from Kalimantan to Madagascar. Norwegian University Press/The Institute for Comparative Research in Human Culture

Dirac C, Andriambelo L, Sorg J-P (2006) Scientific bases for a participatory forest landscape management. Madagascar Conserv Dev 1:31-34

Duffy R (2006) Non-governmental organisations and governance states: the impact of transnational environmental management networks in Madagascar. Environ Polit 15:731-749

Ecole Supérieure des Sciences Agronomiques (2008) Colloque Internation " les parties prenantes de la gestion communautaire des ressources naturelles: coopération, contradictions, conflits". Université d'Antananarivo, Antananarivo

ESSA (2008) Colloque Internationale " les parties prenantes de la gestion communautaire des ressources naturelles: coopération, contradictions, conflits". Ecole Supérieure des Eaux et Forêt, Université d'Antananarivo, Antananarivo

Fedele G, Urech ZL, Rehnus M, Sorg J-P (2011) Impact of women's harvest practices on Pandanus guillaumetii in Madagascar's Lowland Rainforests. Econ Bot 65:158-168

Fennell LA (2011) Ostrom's law: property rights in the commons. Int J Commons 5:1

Ferguson B (2010) Madagascar. Madagascar policy context: forests and conservation. In: Springate-Baginsk O, Wollenberg E (Eds) REDD, forest governance and rural livelihoods. The emerging agenda. CIFOR, pp 135-172

Froger G, Méral P, Herimandimby V (2004) The expansion of participatory governance in the environmental policies of developing countries the example of Madagascar. Int J Sustain Dev 7:164-184

Hardin G (1968) The tragedy of the commons. Science 162:1243-1248

Harper GJ, Steininger MK, Tucker CJ, Juhn D, Hawkins F (2007) Fifty years of deforestation and forest fragmentation in Madagascar. Environ Conserv 34:325-333

Henkels D (2001) A close up of Malagasy environmental law. Vermont J Environ Law 3:1-16

Hockley N, Andriamarovololona MM (2007) The economics of community forest management in Madagascar. Is there a free lunch? An analysis of Tranfert de Gestion. USAID, 81

Hufty M, Muttenzer F (2002) Devoted friends: the implementation of the convention on biological diversity in Madagascar. In: Le Prestre P (Ed) Governing global biodiversity. Ashgate, pp 279-309

Husson O, Tuan HD, Boyer J, Chabanne A, Caesar-Thon That TC, Seguy L (2003) Impacts of direct planting on permanent soil cover techniques on soil. Biological activity in northern Vietnam, CIRAD, Madagascar. http://agroecologie.cirad.fr

Jarosz L (1993) Defining and explaining tropical deforestation: shifting cultivation and population growth in colonial Madagascar (1896-1940). Econ Geogr 69:366-379

KAM (2009) Dossiers de transfert de gestion des ressources forestières à la communauté de base TITFS à Moronivo. Commune de Manompana, KoloAla Manompana

Keller E (2008) The banana plant and the moon: conservation and the Malagasy ethos of life in Masoala, Madagascar. Am Ethnol 35:650-664 
Keller E (2009) "Who are they"? Local understanding of NGO and state power in Masoala, Madagascar. Tsantsa 14:76-83

Kull CA (2002) Madagascar aflame: landscape burning as peasant protest, resistance, or a resource management tool? Polit Geogr 21:927-953

Kull CA (2004) Isle of fire. The political ecology of landscape burning in Madagascar. The University of Chicago Press, Chicago, London

Leach M, Mearns R, Scoones I (1999) Environmental entitlement: dynamics and institutions in community-based natural resource management. World Dev 27:225-247

McConnell WJ, Sweeney SP (2005) Challenges of forest governance in Madagascar. Geogr J 171:223-238

Montagne P, Bertrand A (2006) Histoire des politiques forestières au Niger, au Mali et à Madagascar. In Bertrand A, Montagne P, Karsenty A (Eds) L'état et la gestion locale durable des forêts en Afrique francophone et à Madagascar. L'Harmattan, pp 54-83

Muttenzer F (2006) Déforestation et droit coutumier à Madagascar l'historicité d'une politique foncière. $\mathrm{PhD}$ thesis. Université de Genève, Genève, 564

Muttenzer F (2006) Fiscalité, corruption et culture de "l'État forestier" à Madagascar. In: Froger G (Ed) La mondialisation contre le développement durable? P.I.E.-Peter Lang, pp 235-256

Muttenzer F (2010) Déforestation et droit coutumier à Madagascar. Les perceptions des acteurs de la gestion communautaire des forêts. Karthala, Institut de hautes études internationales et du développement, Paris, Genève

Ostrom E (1999) Self-governance and forest resources. Occasional Paper No 20, CIFOR

Ostrom E (2001) Reformulating the commons. In: Burger J, Ostrom E, Norgaard RB, Policansky D, Goldstein BD (Eds) Protecting the commons: a framework for resource management in the Americas. Island Press, pp 17-41

Persha L, Agrawal A, Chhatre A (2011) Social and ecological synergy: local rulemaking, forest livelihoods, and biodiversity conservation. Science 331:1606-1608

Pfund J-L (2000) Culture sur brûlis et gestion des ressources naturelles. Evolution et perspectives de trois terroirs ruraux du versant est de Madagascar. PhD thesis. ETH Zürich and EPFZ Lausanne, Zurich, 323

Pfund J-L, Watts J, Boissiere M, Boucard A, Bullock R, Ekadinata A, Dewi S, Feintrenie L, Levang P, Rantala S, Sheil D, Sunderland $\mathrm{T}$, Urech ZL (2011) Understanding and integrating local perceptions of trees and forests into incentives for sustainable landscape management. Environ Manag 48:334-349

Pollini J (2010) Environmental degradation narratives in Madagascar: from colonial hegemonies to humanist revisionism. Geoforum 41:711-722

Rabesahala Horning N (2004) The limits of rules: when rules promote forest conservation and when they do no-insights from Bara country, Madagascar. PhD Dissertation. Cornell University, Cornell

Rabesahala Horning N (2008) Madagascar's biodiversity conservation challenge: from local- to national-level dynamics. Environ Sci 5:109-128

Rabesahala Horning N (2009) Bridging the gap between environmental decision-makers in Madagascar. In German LA, Karsenty A, Tiani A-M (Eds) Governing Africa's forests in a globalized world. Earthscan, pp 234-252

Rabesahala Horning N (2010) Réduire l'écart entre les décideurs en matière d'environnement à Madagascar. In: German LA, Karsenty A, Tiani A-M (Eds) Gouverner les forêts africaines à l'ère de la mondialisation. CIFOR, pp 259-284

Rabenilalana M, Rajoelison LG, Sorg J-P, Pfund J-L, Rakoto Ratsimba H (2010) Multi-temporal analysis of forest landscape fragmentation in the North East of Madagascar. In: Forest landcsapes and global change. New frontiers in management, conservation and restoration, Bragança, Portugal

Raik DB, Decker DJ (2007) A multisector framework for assessing community-based forest management: lessons from Madagascar. Ecol Soc 12:14

Rakotoarison HH (2009) Revenus ruraux et compensation pour services environnementaux. Cas du corridor forestier de Manompana, district de Soanierana Ivongo. Mémoire de diplôme. Université d'Antananarivo, Antananarivo, 157

Rakotomavo A (2009) Schéma d'aménagement du site KoloAla Manompana. Report, AIM, Union Européenne, Manompana, 61

Rakotovao Andriankova S, Razafindrabe M, Betrand A (1997) Vers la gestion communautaire locale des feux de végétation à Madagascar. Akon'ny Ala 20:8-22

Ramamonjisoa BS (2004) Origines et impacts des politiques de gestion des ressources naturelles à Madagascar. Schweizerische Zeitschrift für Forstwesen 155:467-475

Rambeloarisoa G, Razafy FL (2008) Transfert de gestion des ressources naturelles auprès des communautés de bases, les leçons apprises. In Colloques international: "les parties prenantes de la gestion communautaire des ressources naturelles: coopération, contradictions, conflicts”, Antananarivo, Madagascar. pp 33-38

Randriamalala H, Rasarely E, Ratsimbazafy J, Brizzi A, Ballet J, Razakamanarina N, Ratsifandrihamananana N, Schuurman D (2011) Stocks de bois précieux de Madagascar - quelle voie emprunter? Madagascar Conserv Dev 6:88-96

Randrianatoandro Andrianavalona E (2009) Décentralisation - Information et communication sur les questions aménagement du territoire et gestion des ressources naturelles. Mémoire des diplômes. (Not published). Université d'Antananarivo, Antananarivo, 130

Razafy FL (2004) Les intérêts des différentes acteurs dans la gestion des ressources naturelles forestières. Schweizerische Zeitschrift für Forstwesen 155:89-96

Samisoa A (2001) Migrations et déforestation sur le plateau calcaire de Belomotse-Vineta. In: Razanaka M, Grouzis P, Milleville P, Aubry C (Eds) Sociétés paysannes, transitions agraires et dynamiques écologiques dans le Sud-Ouest de Madagascar. Institut de Recherche pour le Développement, pp 53-62

Samyn J-M (2006) Participation: how to minimize risks and limitations? Schweizerische Zeitschrift für Forstwesen 157: $477-482$

Schlager E (2007) Community management of groundwater. In: Giordano M, Villholth KG (Eds) The agricultural groundwater revolution. Cabi, pp 131-152

Schmidt K (2007) Livelihoods and forest management in transitionknowledge and strategies of local people in the walnut-fruit forests of Kyrgyzstan. PhD thesis. University of Reading, Reading, 406

Serpantié G, Toillier A, Ratolojanahary M, Rasimisetra L and Carrière S (2008) Mieux négocier les règles techniques de la gestion contractuelle des forêts, pp 13-23. In: Colloque International "Les parties prenantes de la gestion communautaire des ressources naturelles: coopération, contradictions, conflicts". Département des Eaux et Forêts de l'ESSA, Université d'Antananarivo, Antananarivo, Madagascar

Shvidenko A, Sven Erik J, Brian F (2008) Deforestation. In: Encyclopedia of ecology. Academic Press, pp 853-859

Shyamsundar P, Kramer RA (1996) Tropical forest protection. J Environ Econ Manag 31:129-144

Sodikoff G (2009) The low-wage conservationist: biodiversity and perversities of value in Madagascar. Am Anthropol 111:443-455

Sola G (2010) Etude des filières bois formelles et informelles issues de deux zones forestières de la côte est de Madagascar. Travail de diplôme, AgroParisTech-ENGREF, CIFOR, AIM, Montpellier 
Styger E, Rakotondramasy HM, Pfeffer MJ, Fernandes ECM, Bates DM (2007) Influence of slash-and-burn farming practices on fallow succession and land degradation in the rainforest region of Madagascar. Agric Ecosyst Environ 119:257-269

Tole L (2010) Reforms from the ground up: a review of communitybased forest management in tropical developing countries. Environ Manag 45:1312-1331

Uphoff N, Langholz J (1998) Incentives for avoiding the tragedy of the commons. Environ Conserv 25:251-261
Urech ZL, Rabenilalana M, Sorg J-P, Felber HR (2011) Traditional use of forest fragments in Manompana, Madagascar. In Colfer CJP, Pfund J-L (Eds) Collaborative governance of tropical landscapes. Earthscan, pp 131-155

Varughese G, Ostrom E (2001) The contested role of heterogeneity in collective action: some evidence from community forestry in Nepal. World Dev 29:747-765 